\title{
Activités
}

1-2 | octobre 2004

Activités et action / Cognition située

\section{Situated action in the development of activity}

\section{Pascal Béguin and Yves Clot}

\section{OpenEdition}

\section{Journals}

\section{Electronic version}

URL: http://journals.openedition.org/activites/1242

DOI: 10.4000/activites.1242

ISSN: $1765-2723$

\section{Publisher}

ARPACT - Association Recherches et Pratiques sur les ACTivités

\section{Electronic reference}

Pascal Béguin and Yves Clot, « Situated action in the development of activity », Activités [Online], 1-2 octobre 2004, Online since 01 October 2004, connection on 11 December 2020. URL : http:// journals.openedition.org/activites/1242 ; DOI : https://doi.org/10.4000/activites.1242

This text was automatically generated on 11 December 2020.

\section{(c) $($ i) $(9)$}

Activités est mis à disposition selon les termes de la licence Creative Commons Attribution - Pas d'Utilisation Commerciale - Pas de Modification 4.0 International. 


\title{
Situated action in the development of activity
}

\author{
Pascal Béguin and Yves Clot
}

\section{ERRATA}

An anomaly during the automatic migration of all texts published in 2015 to the current e-platform resulted in a reversal of the names of the authors of the paper entitled "Situated action in the development of activity". This error has now been fixed (December 2020). The editorial board wishes to apologize to the authors and readers for this mistake.

1 What do situated action theories contribute to activity theories? This debate is already well underway in international literature (see for example, Nardi, 1996 or Engeström, 1999). We will conduct the debate based on relations between the functioning and development of activity. We have discussed these relations elsewhere (Clot, 2004). In this article we will tackle it from the perspective of situated action. Relations between the functioning and development of activities are interesting for two reasons. First they allow us to hold the discussion based on a question common to Soviet activity theories (as they were initially developed by Vygotski, Leontiev and Bakhtin), the French-speaking approach in psychology (Wallon, Piaget, etc.) and ergonomics (where the notion of activity is almost synonymous with inventiveness). Second, we feel it is urgent to clarify relations between the given and the created in activity, both in work psychology (Clot, 1999; Clot, \& Faïta, 2000) and ergonomics (Béguin, \& Cerf, 2003). ${ }^{1}$

2 However, there is a profusion of situated approaches: they contain references to philosophy (pragmatic, phenomenological), to sociology (Chicago School and ethnomethodology, social phenomenology), to anthropology (particularly cognitive anthropology), to psychology or engineering sciences (including artificial intelligence). Yet first we will try to find our way, even briefly, around situated cognition and action 
theories (without by any means claiming exhaustiveness). Thereafter, we will discuss relations between the given and the created.

\section{Situating the organization of action}

Situated cognition and action approaches aim to provide a theory for the organization of action, rather than to characterize a particular type of action ${ }^{2}$. More specifically, debates concern relations of determination between the subject and the situation, between the internal and the external: where should we situate the organization of action? Conein and Jacopin (1994) argue that in situated movements, the "organization of action is understood as a system emerging in situ from the dynamic of interactions" ( $p$ 476). What should we understand by the term "dynamic of interactions"? And what does "emerging" mean? Clearly, we can identify different answers and even different traditions. We will distinguish three ${ }^{3}$. The first, which we will call "interactionist" mostly originates in sociology. The second, qualified here as "ecological", is more directly grounded in psychology. The third, qualified here as "cultural", is close to cognitive anthropology.

\subsection{The interactionist approach}

4 When discussing interest in the situation within the organization of action, one often refers to Goffman: we cannot treat situation like a country cousin. Usage of a word, however, is not enough to ensure the problem is tackled with precision. It is more exactly defining situation by means of interactions (and even one-to-one interactions) that interest Goffman. Indeed, when participants are in immediate physical contact with one another, they contribute together to the same global definition of the situation (Goffman, 1959). This acceptance of the notion of situation, inherited from symbolic interactionism, is not common in ergonomics or psychology: why define situation as being born of "interaction"?

5 The answer probably comes from the history of sociology, particularly in the debate that opposes functionalist sociology (Durkheim or Parsons) and interpretive sociology (one of whose leaders is H.G. Mead). While functionalist sociology argues that social structures weigh on the behavior of each person via the restrictive role of norms, interpretive sociology insists on society being produced by agents' behavior.

6 Symbolic interactionism in particular "understands society to be something that is lived here and now, in the face-to-face and mediated interactions that connect persons to another [...] Society, like interaction, is an emergent phenomenon" (Denzin, 1992, pp. 22-23). Social structures undergo interpretation and social order is the product of well-ordered improvisation (Mead, 1934). Individuals thus create the world in which they live via their interactions (Blumer, 1969). Ethnomethodology takes this interactionist position further. The hypothesis of positivist sociology, which claims that we act in response to an objectively given social world, is replaced by the hypothesis that says our everyday social practices make the world mutually intelligible: to make sense of the everyday world, subjects have methods at their disposal. These methods are the object of ethnomethodology, and the theoretical background for Suchman (1987), who was the first (to our knowledge) to put forward the term "situated action". 


\subsubsection{From plan to situated action}

7 While Suchman's interactionist approach is situated above all in the field of sociology, her work is interesting precisely because it is not limited to this. Quite the contrary, Suchman draws a parallel between the norms of functionalist sociology and the plans of cognitive computational psychology. Both suppose the existence of potentially countless background affirmations and presuppositions, to which our attitudes and actions respond. However, Suchman affirms that neither of them manages to account for the carrying out of action.

Indeed, when one produces experimental situations during which subjects are asked to provide these background affirmations, we realize that they are not available and, on the contrary, they must be produced. Suchman deduces that the plan is engendered in the rational field to account for action but it is not at all necessary for its realization. All the more so because no matter how much the agent plans and envisages alternatives to choose from at each stage, accomplishing action cannot be the simple execution of a plan. It is necessary to adapt to circumstances, deal with contingencies, and act at the right time in seizing favorable opportunities. Thus, writes Suchman: "I have introduced the term situated action.. That term underscores the view that every course of action depends in essential ways upon its material and social circumstances. Rather than attempting to abstract action away from its circumstances and represent it as a rational plan, the approach is to study how people use their circumstances to achieve intelligent action" (Suchman, 1987, p. 50).

9 In short, the plan is either a resource (when it is produced before the action) that plays an orienting role (she takes the example of a kayakist who plans to undertake a particular action when he/she reaches a given marker), or is produced afterwards, a reconstruction sui generis that aims to take action as an object of reflection after it is carried out ${ }^{4}$. It does not account for action under way. Effective action emerges from circumstances".

\subsubsection{From carrying out action to its construction in situation}

10 If we cannot account for the carrying out of action based on existing knowledge (cognitive computational psychology's plans or functionalist sociology's norms) what does allow us to account for it?

11 Suchman looks to verbal communication for the prototype of a contextual approach to action in line with Schutz's position, according to which our shared understanding of situations is largely due to the efficiency of language, "the typifying medium par excellence". Two dimensions account for the contextualization of action: "indexicality of language" and "reflexivity of purposeful action".

Indexicality of language refers to the fact that an expression takes on meaning in circumstances, in what is presupposed (an expression such as "big apple" means New York if we use it when in Manhattan) or in what is perceived or indicated (as is the case in the usage of deictics - personal pronouns and time, place or demonstrative adverbs). Indexicality thus refers to the fact that language has a strong contextual dependence that subjects exploit ${ }^{5}$. Reflexivity of purposeful action means that language defines the frame of the action. Situated language is not only grounded in, but largely constitutes, the situation of its use. In contrast with a normative paradigm (where language 
vehicles given social conventions) language creates and sustains shared understanding on specific occasions of interaction.

Finally, in Suchman approach, saying that action emerges from circumstances means two things: action is dependent on circumstances (this is indexicality) and acting defines the context of action (this is reflexivity). However, the dynamic of interactions is essentially language-based. Enunciation allows it to be grounded in the situation. Enunciation also defines the frame of action. While speaking contextualizes and situates action in the situation, it remains to be seen where situated approaches place the organization of action when verbal interactions play a minor role in its effective application.

\subsection{The ecological approach: practical thought}

Suchman's position can be considered as phenomenological: one needs to identify the properties of action before it has been converted into an object in the rational field (anticipated before the fact, or reconstructed afterwards). However, this approach does not cover the whole field of situated action. Other movements fit into a perspective that can be described as "ecological", insofar as some of the tasks [particularly the cognitive tasks, which can lead to talk not of situated action but rather, situated cognition (Conein, \& Jacopin, 1994)] are transferred to the environment.

The ecological approach was born of doubts on the validity of experimental situations to account for thought in situations of daily life. We could thus distinguish an academic or theoretical thought mode [see Neisser (1976), who defines AI, half-joking, halfserious, as Academic Intelligence] and a practical thought mode (Scribner, 1986), whose specificity lies in the fact that it is finalized ${ }^{6}$.

We will use work analysis conducted by Beach (1993) to exemplify the ecological approach. The author looks at strategies used by cafe waiters to memorize customer orders. These waiters use the positions of glasses (empty or full) on the bar, as well as clues on the customers' tables (position or state of coasters) to memorize certain elements of customer orders. However, "integrating the environment into the problem solving system" is not immediate. Beach observes that the operators first use verbal clues. And as expertise gradually develops, barmen use information available in the environment more and more. Scribner indicated the interpretation of such findings by writing, "If experts in a domain use the environment more (or more effectively) than novices [...] models of thinking that can only deal with the world as represented in the head may find analysis of many practical thinking problems intractable" (Scribner, 1986, p 25). Becoming expert means exploiting environmental resources.

In the ecological approach, "situated" means that part of the action organization is taken care of by the environment. Nonetheless, several versions are possible. We can look to the environment for elements that orient and structure the subject's action, or on the contrary, explore how the subject exploits the environment.

\subsubsection{Grounding action}

Speaking of grounding action means that representations are placed and made available in the physical world. This movement draws above all from Gibson's ecological psychology (1979). The central idea is that we directly perceive the 
functional value of objects and their practical signification: what should be done, the risks or obstacles. This is the notion of affordance, interested in perception, which postulates economic mechanisms in information processing (the notion of affordance is in fact borrowed from K. Lewin and Gestalt; we will come back to this point). Affordances are characterized as follows:

- The object is significant; this signification is linked to perceptual experience (particularly to traces left in later experiences).

- An object is immediately associated with a signification for action.

Brooks (1991), for example, argues that experts hardly plan at all. They use skills and rules of action that are grounded in the ability to distinguish perceptual clues. One can thus speak of "routines". A routine is situated because it exploits "what is at hand" for action. Rather than an abstract reasoning on representations of the world, action reaches the world directly by perception and manipulation. Such an approach deals with the routine as "emerging from concrete activity". (Chapman, \& Agre, 1987).

"Routines" highlight a difference that has often been seen as fundamental within debates opposing situated action approaches and cognitive psychology. The latter postulates that cognition can be defined as a formal manipulation of symbolic representations. In the ecological approach, and particularly that most focused on the notion of affordance, coupling occurs via perception or the carrying out of action. The notion of symbolic treatment loses a good deal of its heuristic interest.

21 We will make two further remarks. In doing without the computational hypothesis, the approach postulates doing without mechanisms for processing information: they are transferred to the environment. For this reason, it interests many sectors, from studies on cognitive burden in the workplace (Kirsh, 2001) to situated approaches in A.I. (where we speak of a "situated agent", (Maes, 1990). Our second remark: this approach has been qualified as spatial (Conein, \& Jacopin, 1994), in that action is grounded thanks to representations available in (physical or social) space. Nonetheless, the temporal variable cannot be neglected insofar as the routine emerges from interaction with the environment (Chapman, \& Agre, 1987).

\subsubsection{Handling the situation}

Grounding action raises debate within the ecological approach. Kirsh (1995), for example, also starts with the idea that experts do not plan. But he adds another idea: experts "jig" their environment. "Jigging is one way of preparing and structuring the environment. The more completely prepared the environment is, the easier is it to accomplish one's task" (Kirsh, 1995, p 37). This scheme postulates that action is heterogeneous to an extent; part of action consists in attaining a goal, whereas another part organizes the environment to adapt it to action. The process of structuring the environment, that Hammond, Converse and Grass (1992) call "the stabilization of environments", constitutes an "active", rather than a "reactive" dimension of action. From our point of view, this position is very distinct from the preceding one because action is active. Rather than exploiting available resources within the environment, the subject creates resources of his/her own action. Work by Scribner (1986) and Lave (1988) will serve as examples here.

To account for the distinction between given and created, Lave suggests distinguishing two elements in the situation: (i) the arena, which is the objective spatial environment; 
this is the "given" situation, (ii) the setting, i.e. the situation constructed as a result of the subject's activity; this is the situation as a product of activity. In a supermarket, for example, the arena is defined by the position of articles on the shelves and the organization of these shelves as determined by marketing managers. However, the setting is defined by the space really explored by a customer (who is the object of strategies, because not all sections are visited), how the products are arranged in the trolley (which, as Lave demonstrates, can act as a memory support), by the shopping list, etc. In this example, part of the organization of action is effectively delegated to the characteristics of the situation, but it concerns the part of the situation created by the subject's activity.

Scribner (1986) also argues that properties of the environment play a role in practical problem solving. Hence, for milkmen in England, the physical state of the milk crates empty or full - or their spatial positions - storage organization - all play a functional role: these variables allow the solving of complex problems of counting and calculating. But the state of the environment is not given in the work. She stresses that the properties of situation take on a functional role due to the initiative and constructive activity of the person solving the problem. In "constructive activity", the subject makes the situation meet and conform to the needs of his/her action.

\subsection{Artifacts and culture}

The cultural approach, which we will essentially illustrate with research by Hutchins ${ }^{7}$, shares a certain number of points with the ecological approach, in particular through the notion of "affordance" and "cognitive artifacts" developed by Norman.

From affordance, Norman (1994) retains the idea that objects serve to control action. "Cognitive artifacts" clarify control's focus. Some artifacts serve to represent action (they aim to facilitate manipulation and execution), others serve as informational supports for action (they facilitate memory and symbol processing) ${ }^{8}$.

Hutchins' research is part of the same movement, yet is different in two ways. First, cognitive artifacts may not be disconnected from cultural variables. Second, he generalizes the approach to groups. This is the distributed cognition movement. In principle, it is possible to do a double reading of this movement (to which the author himself contributed): cognitive or cultural.

In the cognitive approach, cognition is apprehended as a functional system, made up of a person and artifacts, as well as their relations. The components of such a system are defined by their capacity to vehicle representational states. Hence, Hutchins and Klausen (1992) analyze the cockpit as a "cognitive system", where knowledge representation is both in "subjects' heads" and in artifacts, where the representational states propagate via different media. Flor and Hutchins (1991) write that "By studying cognitive phenomena in this fashion it is hoped that an understanding of how intelligence is manifested at the systems level, as opposed to the individual cognitive level, will be obtained."(Flor, \& Hutchins, p 37). This change in unit of analysis (from individual to a broader system) is perhaps necessary. But to get there, distributed cognition places cognitive artifacts and subjects on the same level. Both are understood as supports for information processing. Hence a criticism often leveled at distributed cognition is that it postulates an equivalence between subject and object (Nardi, 1996). 
We share this criticism. Such reductionism seems not very heuristic and difficult to support in a research perspective.

The second reading, developed in Cognition in the Wild (Hutchins, 1995), is cultural. We consider two points as central:

- The first point: human cognitive capacities cannot be disconnected from their natural milieu, which is in reality largely artificial as well as culturally and historically determined. Furthermore, many of these cultural environments fall within the domain of knowledge of practices that language has difficulty accessing. Here, we come back to the idea that cognition is inseparable from cultural productions. This position, which is also held, for example, by Olson (1980), does not eliminate a priori the importance of human cognition. However, it considers that cognition is solicited differently depending on the technologies available. For example, memory is solicited differently based on whether or not writing exists. Hutchins stresses elsewhere that cognitive technologies form a system (artifacts are coherent among themselves, and cognitive tasks imposed on subjects are coherent with artifact systems).

- Point two: "The real power of human cognition lies in our ability to flexibly construct functional systems that accomplish our goals by bringing bits of structure into coordination" (Hutchins, 1995, p 316). What does Hutchins mean? First, there is a division of tasks: each person is responsible for local processing that cannot be understood without reference to the whole.

But above all, this division of tasks is not rigid: there are different architectures. "The group," he writes "can be seen as a computational architecture." As a result, different architectures will have different effects. Hence, certain structures attempt to reduce production of alternative interpretations (they facilitate the decision making process), whereas others, on the contrary, are excessively productive and render decision making impossible.

What does "situated" mean in this cultural approach to distributed cognition? The "situation" does not control action. For Hutchins, there culturally and historically situated (this is the case, for example, of navigating at sea, which Hutchins calls the computational level, in reference to Marr). Nonetheless, action is situated in two ways:

- On the execution of action level (and particularly on the information processing level), given the distribution of cognitive artifacts i.e. informational media.

- On the control of action level (i.e. definition of the goal) in that the definition of individual goals is dependent on the architecture of the group.

\section{The given and the created}

Now we need to attempt to evaluate the impact of the turnaround proposed by situated action approaches. On several aspects, they are an alternative to the cognitivist approach: insistence on analyses in real situations, limiting the functional role of plans, questioning the formal manipulation of symbolic representation, etc. But above all, they insist on action being determined by situational variables, which they inventory. In doing so, they tend to replace subject psychology by situation psychology. As de Fornel and Quéré would say, it is about "putting back into the environment what was unduly removed from it in order to attribute it to the spirit or the subject." (1999, p. 29). 

organization is removed from the agent, and attributed to the structure of the object or system with which he/ she coordinates him/herself. Such is the meaning of "coordinate": "to set oneself up in such a way that constraints on one's behavior are given by some other system" (1995, p. 200). In these conditions, de Fornel and Quéré are correct in writing that in distributed cognition, "the control of the situated action is due to an external instance, that takes the place of the mental pilot of rationalist models." (1999, p. 28). But we can find a common denominator: "What makes individual thought possible is the existence of a stable environment of thoughts, conceptions, representations and significations that are nobody's, that, in short, come from an "objective spirit" supported by society's practices, customs and institutions." (de Fornel, \& Quéré, 1999, p. 28). And in this perspective, after Gibson (1979), there is much stress placed on the functionality of affordance through which a subject detects structural invariants corresponding to permanent properties of the environment. Extraction of these "socially supported" invariants can even be taken as automatic: "Anyone familiar with the ways of doing and thinking in a culture, its customs, the objects and mechanisms it uses, its techniques and methods, immediately and directly perceives the affordances of objects." (Quéré, 1999, p.318-319). Thus there is no need, in this ecological perspective, to hypothesize about a mental interface between the subject and the world. There are "behavioral milieux", in which are deposited "shared values, i.e. the social rules that people give themselves and agree to follow because they make sense." (p. 334). This "coupling between environment and behavior, situation and conduct", contributes to "reduce the hold of the metaphysics of subjectivity on social investigation." (de Fornel, \& Quéré, 1999, p. 29). At the end of the day, affordance, artifacts or the structure of social groups are generally thought of as the invariant of situated action. These situational invariants organize the subject's conduct and activity.

This is a serious shift away from a planned and endogenous conception of action. And for anyone interested, as we are, in the historical and cultural dimension of activities and their resources, theoretical developments of "situated action" are certainly interesting. Even better, we can consider that they confirm our own analyses. We will particularly recognize, in taking physical and social contexts into consideration, not only a condition for action but also a constituting element of action. or pre-organized, stable forms of action operations and what we call the concept of activity. Is not all activity situated precisely between the given and the created? Work analysis familiarized us with the weight of what has already been decided, what is given or "crystallized" in structures. But it also taught us that activity cannot be reduced to execution procedures applied more or less passively. Furthermore, even the most repetitive movement of a production line worker is always unique. So, we can understand why Vergnaud and Récopé, in a Piagetist perspective, could correctly write that the scheme is not a stereotype: "What is invariant is the organization of activity, not activity." (Vergnaud, \& Récopé 2000, p. 45).

This distinction seems essential to us: activity makes use of what is given in advance, what is preorganized or crystallized and what we call by the generic term "invariants" but cannot be confined to them: on the contrary, activity makes use of invariants. 
Clearly, situated action theories seek invariants in the situation, rather than in the subject as is the case in cognitive psychology. However, in arguing that the invariants situated in situations explain activity, situated approaches reduce the distinction between the invariant, the already given, and the created in activity. As a result, it would appear to be more a shift than a turnaround in traditional cognitive psychology.

In the field of situated action, we will no doubt find convincing counter-examples, like Laborde's analyses on improvisation (1999), or those of Sribner (1986) and to a lesser degree Lave (1988), which we referred to above. But the tendency of confining action to the situation in which it takes place, and seeking control of action, both in its contents and realization, is characteristic of "situated action".

We prefer to think that it is activity, unique at every occurrence, that must be confronted with situations in their physical and social components. The structural invariants of situated action are surely the organizers of activity in situation. But they are not the activity itself. Seen from this angle, it appears that situated action theories, like the most cognitive of approaches to action, are not attentive enough to the benefits that can be drawn from the distinction between functioning, backed up by the invariant, the already constructed or the given, and the development of invariants in activity.

\section{Functioning and development}

In attempting to repatriate the subject into the situation, in reintegrating him/her socially, situated cognition and action approaches clearly indicate a limit to cognitive psychology, including those that are explicitly interested in development, like Piaget. Pastré (2000) made this clear. While for Piaget development is vital, it is endogenous. The milieu only has a secondary impact in the development of an epistemic subject distanced from the "specific content" of action and which supposedly "develops all by itself" (Pastré, 2000, p. 48). We can only wonder whether, to avoid abstractions of the psychological subject, situated approaches have not simply exported invariants into the situation itself to de-psychologize them. In this case, they simply transferred them: socialized, "distributed" and external to the subject, at the risk of eliminating the subject's activity. This opens the door to a pure "situations logic" in the sense given by Poppers: a method that consists in sufficiently analyzing the acting subject's situation so as to explain his/her action based on the situation. (Popper, 1979).

In short, on one hand we have an endogenous development of the subject but the place of situations is unclear. On the other, we have an exogenous development of the situation but the subject's role is unclear. We put forward the hypothesis that situated action theories transpose into situations what cognitive psychology situated in the subject, shifting the paradoxes without solving them. If this is the case, the announced turnaround, even in making individual activity obsolete, even in purely and simply reducing subjectivity to intersubjectivity (Valsiner, 1997; Grossen, 2001), would be more a pendulum movement than an effective alternative. This is not completely new in the history of psychology. We can only be struck by the similarity between perspectives of situated action and those of Gestalt theory made famous by W. Köhler et K. Lewin, as noted by Grossen (2001, p. 61). De Fornel and Quéré insist heavily on this and go even further in this direction (de Fornel, \& Quéré, 1999, pp. 14 and 25; Quéré, 
1999, pp. 305 and 330). But as we will see, Wallon had already criticized this epistemological pendulum back in 1942.

\subsection{Subject and situation: a historical overview} to comparing "consciousness psychologies" and "situations psychology". In the former, he places Piaget, who limits application to the individual (1970, p. 46). He notes: "Despite his rigor, Piaget's conception remains fairly eclectic. After initially presenting motor schemes as essential and their individual activities, operating under the control of experience, as the only factors in psychic development, he can then not avoid adding global action." (p. 35). This is development understood as a vital assimilation tendency. Hence, "the subject's and the situation's points of view would have priority over that of the constituent elements. But this is contrary to the explanation system proposed. The principle that had been eliminated in the premises is reintroduced during the explanation." (p.36). And indeed if "the motor schemes have the attributes of autonomous and conquering activity," how do we "seize the moment where the subject will finally emerge from the schemes?" Is the subject not "ultimately discovered there because he/she was presupposed there"?

on then examines another possibility: "The object of psychology can be not a subject but a situation". In this case, "the act is considered from outside, with no postulate of consciousness or person." (p. 50). In this perspective, he examines Gestalt theory, which he recognizes for going back "before the distinction between subject and object." (p. 78). While we can grant that in this theory there is no "primitive duality" between the two, we cannot accept the mutilation of reality that it ends up proposing. At the end of the day, there is indeed a "progressive split in two", an evolution, a development "that follows on from resolved difficulties or conflicts." (p. 78). Instead of this, Gestalt theory reunites object and subject in a whole that is constituted at every instant by external and internal circumstances that "reciprocally choose each other." (1949, p. 57-58). It reunites them in a force field that is a "structure principle", efficient by coincidence, in the suddenness of circumstances. Here, we were able to speak of an instantaneous genetism that gives rise to a state of stable balance where everything that could happen does (Simondon, 1989, p. 46-49). In fact, for Wallon, the Gestalt theory - of great interest to certain movements of situated action concerned with "lessening" the subject's burden - "is a psychology where all that counts is successes that are sufficient unto themselves. Preliminary attempts supposedly have nothing to do with efficiency, attempts that do not succeed are considered as non-existent." (p. 77). Yet, according to him, "even unfruitful attempts are not only negative. They allow the prolongation of the acute phase of the act, that where non-success aggravates the conflict between need, desire, emotional or vital necessity and the obstacle: this leads to reconfiguration, elimination of customary reactions, old structures and regrouping into new structures." (p. 77). In fact, Gestalt "indeed puts the spotlight on the intervention as an original and creative fact, but it makes it into an absolute, a miracle or pre-destination, removed from life, from psychic potential and no longer finds its explanation there." (p. 78).

Finally, for Wallon, consciousness psychology and situation psychology remain caught up in the subject/object confrontation. However, "when contradiction becomes 
evident, it must be resolved. Avoiding it means doing quite the opposite. The easy way out is to assimilate the two terms. Another is to eliminate one of them." (p. 78). We know that for Wallon, only activity simultaneously brings them together and opposes them. It is in activity and activity alone that the relation between given and created as well as functioning and development occurs. The formation of structure does not come from above, as in Gestalt theory, nor is it one-sided as with Piaget. Instead, it rises from activity's conflicts with the obstacle. Development comes out of these conflicts, in that it is born of them and moves away from them. The invariant thus has a history available to the subject. He/she moves beyond it when necessary and possible, not by denying it but through the development of his/ her activity.

\subsection{Development: repetition without repetition}

Yet the way this development works does not easily enter frames of situated action theories that alternate - or even oppose - stabilized routines of ordinary life and events with no history. On one hand, repetitions, which become routines, are taken literally. On the other, creation is seen as a break with the past, which takes on the various attributes of "creationism". We could understand in this way the difference between interactionist approaches in situated action and those that favor affordance and distributed cognition. While the latter favor the invariance of situations, artifacts or group, the former insist on the creation of contexts by a focal event during interaction, in line with intersubjective dynamics. (Grossen, 2001, p. 66).

Indeed, carrying out any action supposes the presence of external and internal invariants. But to put it like Leontiev, the formation of an action cannot be reduced to the formation of invariants, particularly because it is not the result of it. On the contrary: they are the product of actions repeated during non-restorable activities (Leontiev, 1958, p. 176) ${ }^{10}$. Thus, invariants do not engender activity. They do not explain $i^{11}$. On the contrary, activity deals with invariants. Repetition is never repetitive, (Bernstein, 1996; Fernandez, 2001) first because there is no invariant activated without a history of activity that is specific each time; second, because each (specific) activity, either in the form of consolidation or development, deals with the invariant repertory (Clot, 2003, 2004).

Seen in this way, action is not so much situated in the situation as in the activity. Obstacles, disagreements, objective, subjective or intersubjective conflicts encountered in activity generate tension to varying degrees of intensity and invite the subject to mobilize and develop invariants. From the situation, action can - and often must come out. It is always situated but often between and in several situations, in a history and geography of the activity that is specific each time. This is why, if it is very important to grant a central action organizing function to an invariant, it is also necessary to not ask too much of the already constructed. The inference of invariants that gives form to action responds to the interference of activities in changing contexts, which are sources of variations.

\subsection{Activity and interactivity}

If there is no activity without pre-organization or given, likewise, there are no exchanges without initially shared signification. From this point of view, we could take 
up the classic idea of interactionism put forward by Schütz, according to which shared significations, given beforehand for each person, are required for communication. But on one condition: seeing communication as the transformation and real development of required significations. As Vygotski indicated, "People only communicate with one another through significations in proportion to the development of significations" (Leontiev, 2002, p 319).

We now understand better why the work of Bakhtin could be read as an alternative to interactionism in a remarkable article by C. Bender (Bender, 1998, p. 193): "Dialogue is not only possible, but perhaps enlivened when people do not share meaning. What we share is not as interesting as what we don't share."

As a result, action supposes shared consciousness not only of a signification community but also of the different meanings each person attributes to these significations. Awareness of this difference is also required for communication. It is even the driving force. As Vygotski indicated: "Signification does not coincide with logical signification (That which does not have meaning has a signification)" (Leontiev, 2002, p. 310; Vygotski, 2003). We can thus assume that the range of positions within heterogeneous groups of actors constitutes not only a motor for development of their exchanges but more broadly a motor for the development of their activities (Béguin, 2004). We learn by encountering something new, not from something shared.

51 For Bakhtin (1993), the subject -with the help of a shared given- participates in events in a particular position that is his, hers, yours or mine and cannot be replaced by anyone else. Unlike Blumer, for example, who claims that communication effected by incomprehension is ineffective and the formation of the corresponding action is blocked (1969), Bakhtin considers incomprehension as the real source and conflict as the motor of communication development. It is also the real source of comprehension itself. But it is true then that we must take seriously the difference between intersubjectivity and subjectivity, between interaction and action, between activity and interactivity.

Otherwise, yet again, we entrust the invariant of exchanges with engendering them, at the risk of making their development incomprehensible. We are then constrained, as Wallon would say, to turn development into a "miracle" or make do with the magic of subjectivity without activity. More prosaically, we prefer seeing development as a repetition pushed beyond repetition by the overcoming of contexts that renew directed activity (Clot, 1999): a "repetition without repetition". In this frame, the "right form" would be less that of Gestalt theory than one that carries high tension and "judges itself in terms of the quantity of obstacles it manages to conquer," to use Simondon's expression (1989, p. 53).

We can conclude with the remark by Shotter and Billig: In focusing only on what is repeatable and essentially timeless, we talk of ourselves as studying events occurring independently of ourselves $(1999$, p. 25). It is never the case. The repeatable is paradoxically always unique. All in all, perhaps we need to situate action in the development of activity to retain the virtues of creativity and inventiveness that French-speaking work analysis recognizes in action. 


\section{BIBLIOGRAPHY}

Bakhtin, M. (1993). Toward a philosophy of the act. Ed. M. Holquist. Austin, TX: Texas University Press (French translation, 2003, Pour une philosophie de l'acte. Lausanne: L'Âge d'Homme).

Beach, K. (1993). Becomming a bartender: the role of external memory cues in a work oriented educational activity. Applied Cognitive Psychology, 7, 191-204.

Béguin, P. (2004). Dialogisme et conception des systèmes de travail. Psychologie de l'interaction, (sous presse).

Béguin, P, \& Cerf, M. (2004). Essai sur la diversité des formes et des enjeux de l'analyse de l'activité pour la conception des systèmes de travail. @ctivités, $\mathrm{N}^{\circ} 1 / 1$. http://www.activites.org/ v1n1

Bender, C. (1998). Bakhtinian perspectives on "everyday life" sociology. In M. M. Bell, \& M. Gardiner (Eds). Bakhtine and the Human Sciences. London: Sage Publications, pp. 181-195.

Bernstein, N. A. (1996). On dexterity ans its development. In M.L. Latash, \& M.T. Turvey, (Eds). (1996). Dextirity and Its Development. Mahwah New Jersey: Lawrence Erlbaum. Associates, Publischers. Blumer, H. (1969). Symbolic interactionism. Englewoods Cliffs, N.J.: Prentice Hall. Brooks, R. (1991). Intelligence without representation. Artificial Intelligence, 47, 139-160.

Chapman, D., \& Agre, P. (1987). Abstract resoning as emerging from concrete activity. In M.P. Georgeff \& A. Lansky (Eds), Reasonning about abstract and plans. Los altos, CA: Morgan Kauffman Publisher, pp. 411-424.

Clot, Y. (1999). La fonction psychologique du travail. Paris: PUF.

Clot, Y. (2003). La catachrèse entre réel et réalisé. Contribution d'un psychologue du travail. In Y. Clot, \& R. Gori (Eds), Catachrèse : éloge du détournement. Nancy: PUN, pp. 11-27.

Clot, Y. (2004). Le travail entre fonctionnement et développement. Bulletin de Psychologie, 57 (1), 469, 5-12. Clot, Y., \& Faïta, D. (2000). Genres et styles en analyse du travail. Concepts et méthodes. Travailler, 4, 7-42. Cole, M., \& Engeström, Y. (1993). A cultural-historical approach to distributed cognition. In Salomon, G. (Ed.). Distributed cognitions. Psychological and educational considerations. Cambridge: University Press, pp 1-46

Conein, B, \& Jacopin, E. (1994) . Action située et cognition. Le savoir en place. Sociologie du travail, $n^{\circ} 4 / 94,475-500$.

Denzin, N. K. (1992). Symbolic interactionism and cultural studies. The politics pf interpretation. Oxford UK \& Cambridge USA: Blackwell.

Engeström, Y. (1999). Activity theory and individual and social transformation. In Y. Engeström, R. Miettinen, \& R.L. Punamäki (Eds), Perspectives on Activity Theory. Cambridge, New York: Cambridge University Press, pp. 19-38.

Fernandez, G. (2001). Le corps, le collectif et le développement du métier. Etude clinique d\&apos;un geste de métier à la SNCF. Éducation permanente, 146, 27-35.

Flor, N., \& Hutchins, E. (1991). Analysing distributed cognition in software teams: a case study of team programming during perfective software maintenance. In J. Koenemann-Belliveau et al. (Eds), Proceedings of the fourth annual workshop on empirical studies of programmers. Norwood, N.J.: Ablex Publishing, pp 36-59. 
Fornel de, M., \& Quéré, L. (1999). Présentation. Raison pratique. M. de Fornel, \& L. Quéré (Eds). La logique des situations. Nouveaux regards sur l'écologie des activités sociales. Paris: Edition de l'EHESS, pp 7-32.

Gandillac de, M. (1965). Genèse et structure. Entretiens de Cerisy. Paris: Seuil.

Gibson, J. J. (1979). The ecological approach to visual perception. London: Lawrence Erlbaum associates, 1986 ( $2^{\text {nde édition). }}$

Goffman, E. (1959). The presentation of self in every day life. Doubleday, New York: Doubleday (French translation, 1973, Paris: Éditions Minuit).

Grossen, M. (2001). La notion de contexte : quelle définition pour quelle psychologie ? Un essai de mise au point. In J. P. Bernié (Ed.), Apprentissage, développement et significations. Bordeaux: PUB, pp. 59-77.

Hammond, K., Converse, T., \& Grass, J. (1992). The Stabilization of Environments. Artificial Intelligence, 72(1-2), 305-327.

Havelange, V. (1991). Structures sociales et action cognitive : de la complexité en sociologie. In F. Fogelman Soulié (Ed.), Les théories de la complexité. Paris: Seuil, Coll. La couleur des idées, pp. 368-393.

Hutchins, E. (1995). Cognition in the wild. Cambridge, M.A.: MIT Press.

Hutchins, E., \& Klausen, T. (1992). Distributed cognition in an airline cockpit. In Middleton, D., Engeström, Y. (Eds), Communication and cognition at work. Berverly Hills CA: Sage books, pp 15-34. Joas, H., (1999). La créativité de l'agir. Paris: Les Éditions du Cerf.

Kaptelinin, V. (1996). Distribution of cognition between Minds and artifacts: augmentation or mediation? AI \& Society, 10(1), 15-25.

Kirsh, D. (1995). The intelligent use of space. Artificial Intelligence, 73 (1-2), 31-68. Kirsch, D. (2001). A few thoughts on cognitive overlaod. Intellectica, 2000/1, 19-51.

Laborde, D. (1999). Enquête sur l'improvisation. Dans Raison Pratique. M. de Fornel et L. Quéré (Eds), La logique des situations. Nouveaux regards sur l'écologie des activités sociales. Paris: Édition de l'EHESS, pp 261-339.

Lave, J. (1988). Cognition in practice. Cambridge: Cambridge University Press.

Lave J. (1993). Situated learning in a communities of practice. In L.B. Resnick, J.M. Levine, \&, D.S. Teasley (Eds), Perspectives on socially shared cognition. Washington DC: American Psychological Association, pp 63-82.

Leontiev, A. (1958). Réflexes conditionnés, apprentissage et conscience. In Le conditionnement et l'apprentissage, Symposium de l'Association de psychologie scientifique de langue française. Paris: PUF, pp. 169-188.

Leontiev, A. (2002). Le problème de la conscience. Notes sur le rapport de L. Vygotski. In Y. Clot (Ed.), Avec Vygotski. Paris: La Dispute.

Maes, P. (Ed.) (1990). Designing autonomous agents. Cambridge, M.A.: MIT Press. Mead, G.H. (1934). Mind, self and society. Chicago: University of Chicago Press.

Nardi, B. (Ed.) (1996). Context and conciousness. Activity theory and Human Computer Interaction. Cambridge: The MIT Press.

Neisser, U. (1976). The multiplicity of thought. In P.C. Wason \&, P.N. Johnson Laird (Eds). Thinking and reasonning. Baltimore: Penguin, pp. 307-323. 
Norman, D. (1994). Les artefacts cognitifs. Raisons Pratiques, " objets dans l'action », n4, 15-34.

Olson, D.R. (1980). Some social aspects of meaning in oral and written language. In D.R. Olson, (Ed.). The social foundation for language and thought. New York: W.W. Norton.

Pastré, P. (2000). Conceptualisation et herméneutique : à propos d\&apos;une sémantique de 1\&apos;action. In J. M. Barbier, \& O. Galatanu (Eds), Signification, sens, formation. Paris: PUF.

Piaget, J. (1958). Discussion sur la communication de A. Leontiev. In Le conditionnement et l'apprentissage, Symposium de l'Association de psychologie scientifique de langue française. Paris: PUF, pp. 199-201.

Popper, K. (1979). La logique des sciences sociales. In T. Adorno, \& K. Popper (Eds), De Vienne à Francfort, la querelle allemande des sciences sociales. Bruxelles: Édition complexe, pp. 75-90.

Quéré, L. (1999). Action située et perception du sens. Raison Pratique. In M. de Fornel, \& L. Quéré (Eds), La logique des situations. Nouveaux regards sur l'écologie des activités sociales. Paris: Édition de l'EHESS, pp. 301-338.

Rizzo, A., \&, Marti, P. (2000). Distributed cognition and artifacts. http://www-sv.cict.fr/cotcos/ pjs/TheoreticalApproaches/DistributedCog/DistCognitionpaperRizzo.htm

Salembier, P. (1996). Cognition(s) : située, distribuée, socialement paragée, etc. Bulletin du LCPE, $\mathrm{n}^{\circ} 1$, Paris: École normale supérieure.

Schegloff, E.A. (1984). On some questions in ambiguities in conversation. In J.M. Atckinson, \& J. Heritage (Eds) Structures of social action. Cambridge: Cambridge University Press, pp. 25-52.

Scribner, S. (1986). Thinking in action: some characteristics of practical thought. In R.J. Sternberg , \& R.K. Wagner, Practical intelligence. Cambridge: Cambridge University Press, pp. 13-30.

Shotter, J., \& Billig, M. (1999). A backhtinian psychology: from out of the heads of individuals and into the dialogues between them. In M. Mayerfeld, \& M. Gardiner (Eds), Bakhtine and the Human Sciences.

\section{NOTES}

1. Let us note that situated action theories are also of interest to sociology. We will not deal with this aspect in the text but readers may refer to Havelange (1991) or Joas (1999).

2. This point is nonetheless a subject of debate. We could refer to Vera and Simon (1993), for example, who consider situational rationality as a type of rationality.

3. Let us note that other classifications are possible. For example, we could refer to Lave (1993) or Salembier (1996).

4. The status of the plan was not so clear in Suchman's initial formulations. We could refer to Visetti's critical reading (1989) for discussion of this point.

5. This exploitation may fail. Repair mechanisms then come into play - Schegloff, 1984 - i.e. exchanges that aim to reestablish a shared context.

6. In opposition to a form of thought used for isolated or non-significant tasks, carried out as an end in themselves.

7. This approach also interests Vygotski's historical-cultural approach. It thus constitutes grounds for debate between supporters of cognition and action situated theories and activity theories (Cole, \& Engeström, 1993; Kaptelinin, 1996; Rizzo, \& Marti, 2000).

8. It should be noted that this distinction does not correspond to that made by Vygotski between technical tools and psychological tools. 
9. As Maurice de Gandillac noted about the adjective "genetic", contrary to what is often believed, "genesis is not the transcription of the Greek word génésis, from génesthai (become), but that of the Greek word génnèsis, from génnao (engender)" (1965, p. 338).

10. On this point, we can refer the reader to Piaget's commentaries on Leontiev's contribution to the same symposium (Piaget, 1958, p. 199).

11. From this point of view, we will not follow G. Vergnaud and M. Récopé all the way, for whom, beyond the organization of activity, the invariant seems to possess the function of engendering (Vergnaud, \& Récopé 2000, p. 46). We thus can no longer see the role - that they recognize nonetheless - of "contingency" fundamental to this same activity in the formation of invariants.

\section{ABSTRACTS}

After briefly attempting to describe situated action and distributed cognition, we examine their contributions from the point of view of activity theories and more specifically based on the relations between the functioning and development of activity. We argue that situated action identifies a limit in cognitive psychology in seeking to bring the subject back into the situation and in reintegrating him/her socially. However, in situating the organization of action outside the subject, it is finally the characteristics of the situation that explain activity. This epistemological pendulum, already discussed by $\mathrm{H}$. Wallon, does not allow an understanding of the development of activity, nor the relation between what is given in the work situation and what the actors create in the situation.

Après avoir brièvement tenté de rendre compte des différents courants de l'action située et de la cognition distribuée, on examine leurs apports du point de vue des théories de l'activité, et plus particulièrement des rapports entre fonctionnement et développement de l'activité. On argumente que l'action située en cherchant à rapatrier le sujet dans la situation, et en le réincarnant socialement, identifie une limite de la psychologie cognitive. Mais qu'en distribuant les invariants de l'action à l'extérieur du sujet, ce sont les caractéristiques de la situation qui expliquent l'activité. Ce balancier épistémologique, déjà été discuté par $\mathrm{H}$. Wallon, ne permet pas de rendre compte du développement de l'activité, ni du rapport entre ce qui est donné dans la situation de travail et ce qui est créé dans la situation par les acteurs.

INDEX

Keywords: situated action, activity, invariant of action, functioning and development Mots-clés: action située, activité, invariants de l'action, fonctionnement, développement

\section{AUTHORS}

\section{PASCAL BÉGUIN}

CNAM, Laboratoire d'Ergonomie, 41 rue Gay Lussac, 75005 Paris

beguin@cnam.fr 
YVES CLOT

CNAM, Laboratoire de Psychologie du Travail et de l'Action, 41 rue Gay-Lussac, 75005 Paris. clot@cnam.fr 